\title{
New records of Micromys minutus in the Karlovy Vary Region, western Bohemia (Rodentia: Muridae)
}

\author{
Zdeňka KLIMKOVÁ \& Zuzana ČADKOVÁ \\ Department of Zoology and Fisheries, Czech University of Life Sciences Prague, Kamýcká 129, \\ CZ-165 00 Praha-Suchdol, Czech Republic; klimkova@af.czu.cz; cadkova@af.czu.cz
}

received on 29 June 2021

\begin{abstract}
New records of the harvest mouse (Micromys minutus) were obtained for the first time from the mapping square 5741 in the Karlovy Vary Region. The individuals were collected during a faunistic survey of small mammals in 2016-2020. In total, 13 specimens of Micromys minutus were found at three sites (Jindřichovice v Krušných horách, Háj u Jindřichovic, Lomnice u Sokolova).
\end{abstract}

Key words. Harvest mouse, Micromys minutus, new records, Karlovy Vary Region

The harvest mouse, Micromys minutus (Pallas, 1771), is not an unknown species for the Karlovy Vary Region. Its occurrence has been repeatedly documented there, but not in its entire territory. Nests of harvest mice were first recorded in the region in 1962 near Ovesné Kladruby in the Tepelská vrchovina Mts. (mapping square 6045; GRUNDOví 1962) and a year later KuLÍšEK reported findings of 39 individuals in the Smrčiny Mts. (5839; ANDĚra 1994). Through the analysis of owl pellets, the harvest mouse was primarily detected in the Slavkovský les Mts. $(5842,5941,5942)$ and in the years 1973-1974 it was successfully captured in straw stacks (BRDIČKA 1976, 1980).

Due to further analyses of the barn owl (Tyto alba) pellets in the years 1978-1980, the harvest mouse was proved in Cheb (5940), Lomnička, Luby, Milhostov, Plesná, Skalná, Třebeň (5740), Ostrov nad Ohř́, Sedlec (5743), Sokolov, Kynšperk nad Ohří (5841), Staré Sedlo (5842), Hazlov, and Libá (5839), but not in Lomnice (5741; VohraLíK \& LAZAROvá 1998). A summary of the harvest mouse distribution up to the mid-1990s was provided by ANDĚRA (1994), who presented findings from the Podčeskoslezská pahorkatina Mts. - in Milíkov (5941; HŮRKA 1981), Krušné hory Mts. - Boží Dar (5543; Hodková 1979), Cheb Basin - Kopanina (5740), Ostroh (5839; HŮRKA 1981), Skalná (5840; leg. V. ZAVADIL) and Doupovské hory Mts. - Ostrov (5643), Dubina (5743; BuŠEK et al. 1990), and Luka (5844; HoDKové 1979). A survey of soil invertebrate communities using pitfall traps in the Sokolov Basin in the years 1995-2010 showed the presence of the harvest mouse in post-mining localities, namely at the Vintírov spoil heap (5742). However, the species was not recorded at other spoil heaps in the area, namely Habartovská (5841), Vilém (5741), Stará Chodovská (5742; ANDĚRA \& BENEš 2002, ANDĚra \& TAJOvsKÝ 2010). According to ANDĚRA (2011), the harvest mouse was found in the Karlovy Vary Region in Trojmezí (5638), Hranice (5639), Aš (5739), and Měchov (5943).

In order to obtain recent data on the occurrence of the harvest mouse, especially in the central part of the Karlovy Vary Region, a survey of small terrestrial mammal communities was carried out in 2016-2020 using live traps. In total, 36 localities were examined, comprising both undisturbed and post-mining areas. The localities were close to the following settlements (and fell into seven mapping squares): Poturčky (5542), Počátky (5640), Přebuz, Rolava, Kraslice (5641), Nejdek (5642), Dolní Nivy, Háj u Jindřichovic, 
Table 1. Data on the new captured individuals of the harvest mouse (Micromys minutus) in the Karlovy Vary Region. Legend: $\mathrm{W}=$ weight $[\mathrm{g}], \mathrm{H}+\mathrm{B}=$ head and body length [mm], $\mathrm{T}=$ tail length $[\mathrm{mm}], \mathrm{F}=$ foot length $[\mathrm{mm}], \mathrm{E}=$ ear length $[\mathrm{mm}]$

\begin{tabular}{|c|c|c|c|c|c|c|c|c|}
\hline \multicolumn{2}{|c|}{ No. locality } & date & \multirow{2}{*}{$\frac{\text { sex, age }}{\hbar \mathrm{ad}}$} & \multirow{2}{*}{$\frac{W}{8.66}$} & \multirow{2}{*}{$\frac{\mathrm{H}+\mathrm{B}}{65}$} & \multirow{2}{*}{$\frac{T}{63}$} & \multirow{2}{*}{$\begin{array}{c}\mathrm{F} \\
15\end{array}$} & \multirow{2}{*}{$\frac{E}{10}$} \\
\hline 1 & Lomnice u Sokolova & 29 September 2016 & & & & & & \\
\hline 2 & ce v Krušných horách & ptember 2018 & o ad & 5.65 & 57 & 56 & 14 & 11 \\
\hline 3 & Jindřichovice v Krušných horách & ptember 2018 & $\hat{o} \mathrm{ad}$ & 4.69 & 53 & 51 & 12 & 11 \\
\hline 4 & Jindřichovice v Krušných horách & tember 2018 & ㅇ ad & 4.73 & 51 & 56 & 13 & 10 \\
\hline 5 & vice v Krušných horách & mber 2018 & $\hat{o} \mathrm{ad}$ & 5.09 & 51 & 56 & 14 & 10 \\
\hline 6 & Jindři & er 2018 & ㅇ ad & 4.99 & 55 & 53 & 13 & 9 \\
\hline 7 & Jindř & r 2018 & 우 ad & 5.27 & 56 & 60 & 13 & 9 \\
\hline 8 & Jindřic & ember 2018 & ㅇ ad & 4.89 & 52 & 52 & 14 & 9 \\
\hline 9 & Jindřichovice v Krušnýc & tember 2018 & $\hat{o} \mathrm{ad}$ & 4.78 & 51 & 53 & 12 & 8 \\
\hline 10 & Jindřichovice v Krušných horách & 20 September 2018 & o ad & 4.79 & 51 & 53 & 13 & 10 \\
\hline 11 & Jindřichovice v Krušných horách & 20 September 2018 & o $\mathrm{ad}$ & - & - & - & - & - \\
\hline 12 & Jindřichovice v Krušných horách & 20 September 2018 & o ad & - & - & - & - & - \\
\hline 13 & Háj u Jindřichovic & 21 September 2020 & $\hat{o}$ ad & 4.92 & 56 & 56 & 13.5 & 8.9 \\
\hline
\end{tabular}

Jindřichovice v Krušných horách, Lomnice u Sokolova (5741), Královské Poříčí, Chodov, Nové Sedlo u Lokte, Tatrovice, Vintírov, Vřesová (5742), and Krásno (5842).

As a part of this survey, the harvest mouse was found repeatedly in the mapping square 5741 . The first individual was captured in the wetland habitat at the Velká Podkrušnohorská spoil heap at Lomnice u Sokolova (50¹3'21" N, 12 38'50" E; Fig. 1) in 2016, then eleven individuals at Jindřichovice v Krušných horách (50¹6’26” N, 12³6’39” E; Fig. 2) in 2018, and one individual near Háj u Jindřichovic $\left(50^{\circ} 15^{\prime} 10^{\prime \prime} \mathrm{N}, 12^{\circ} 35^{\prime} 57^{\prime \prime}\right.$ E; Fig. 3$)$ in 2020 . The most numerous finding comes from 2018 , when eight adult females and three adult males were recorded during an autumn trapping session. Detailed information on captured individuals is given in Table 1. Similarly to the spoil heap wetland, in the case of Jindřichovice v Krušných horách, it is a rather wet habitat overgrown by Juncus sp. situated between two cattle pastures, and in Háj u Jindřichovic the locality is an ecotone between a field and a field road. In the mapping squares 5542, 5640,5641,5642, 5742, and 5842, occurrence of the harvest mouse was not found during the survey. The individuals captured in 2016 and 2018 were used in further research, and the individual captured in 2020 is deposited in the collection of the Karlovy Vary Museum.

\section{SOUHRN}

Nové nálezy myšky drobné (Micromys minutus) v Karlovarském kraji (Rodentia: Muridae). Myška drobná není pro Karlovarský kraj zcela novým druhem, již v dřívějších dobách byl její výskyt v kraji opakovaně doložen, ne však na celém jeho území. Pro získání recentních dat o výskytu tohoto druhu především ve střední části Karlovarského kraje byl proveden výzkum v letech 2016-2020 pomocí živochytných pastí na celkově 36 lokalitách, jak nenarušených těžbou uhlí, tak i potěžebních. Lokality spadají do sedmi čtverců faunistického mapování a jsou poblíž dále uvedených obcí: 5542 (Potůčky), 5640 (Počátky), 5641 (Přebuz, Rolava, Kraslice), 5642 (Nejdek), 5741 (Dolní Nivy, Háj u Jindřichovic, Jindřichovice v Krušných horách, Lomnice u Sokolova), 5742 (Královské Poříčí, Chodov, Nové Sedlo u Lokte, Tatrovice Vintírov, Vřesová) a 5842 (Krásno). V rámci tohoto sledování byla myška drobná (Micromys minutus) poprvé zaznamenána ve faunistickém mapovacím čtverci 5741 (Jindřichovice v Krušných horách, Háj u Jindřichovic, Lomnice u Sokolova). Celkově bylo nalezeno 13 jedinců; v Lomnici 1 kus roku 2016, v Jindřichovicích bylo roku 2018 nalezeno 11 dospělých jedinců (osm samic, tř̀ samci) a v Háji u Jindřichovic 1 kus roku 2020. 

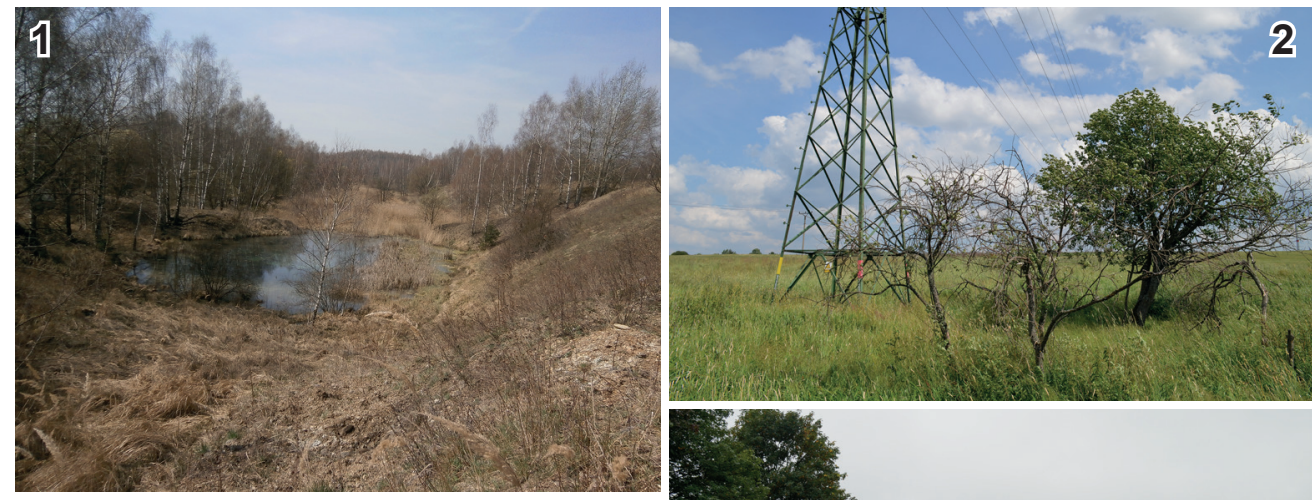

Figs. 1-3. The localities of occurrence of the harvest mouse (Micromys minutus) in the Karlovy Vary Region (photo by Z. KLImkové). 1 - Háj u Jindřichovic. 2 - Lomnice u Sokolova. 3 - Jindřichovice v Krušných horách.

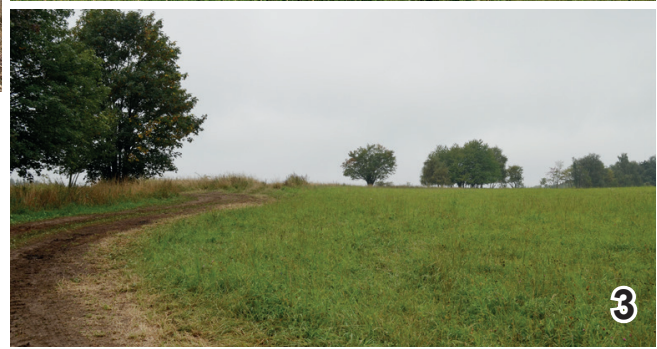

\section{REFERENCES}

ANDĚra M., 1994: Distribution of the harvest mouse (Micromys minutus) in the Czech Republic. Folia Musei Rerum Naturalium Bohemiae Occidentalis, Plzeň, oologica, 40: 1-18.

ANDĚRA M., 2011: Current distributional status of rodents in the Czech Republic (Rodentia). Lynx, n. s., 42: 5-82.

AndĚra M. \& Bentš B., 2002: Atlas rozšírení savců v České republice. Předběžná verze. IV. Hlodavci (Rodentia) - část 2. Myšovití (Muridae), myšivkovití (Zapodidae) [Atlas of the Distribution of Mammals in the Czech Republic. A Provisional Version. IV.Rodents (Rodentia) - Part 2. Mice and Rats (Muridae), Jumping Mice (Zapodidae)]. Národní muzeum, Praha, 116 pp (in Czech, with a summary in English).

ANDĚRA M. \& TAJOvSKÝ K., 2010: Drobní savci ve sběrech Ústavu půdní biologie BC AV ČR v Českých Budějovicích [Small mammals collected by the Institute of Soil Biology BC AS CR, České Budějovice, Czech Republic]. Lynx, n. s., 41: 83-94 (in Czech, with an abstract in English).

BRDIČKA I., 1976: Drobní savci ve stozích ve Slavkovském lese [Small mammals in stacks of the Slavkovský les Mts.]. Zpravodaj Muzeí Západočeského kraje - Př́roda, Plzeň, 19: 69-73 (in Czech).

BrdičKa I., 1980: Savci Slavkovského lesa [Mammals of the Slavkovský les Mts.]. Acta Universitas Carolinae - Biologica, 1977: 199-235 (in Czech).

Bušek O., TeJRovský V. \& Zavadil V., 1990: Obratlovci Doupovských hor (Aves, Mammalia) [Vertebrates of the Doupovské hory Mts. (Aves, Mammalia)]. Sborník Západočeského muzea v Plzni, Př́roda, 76: 1-52 (in Czech).

Grundová S., 1962: Zpráva o nálezu hnízd myšky drobné (Micromys minutus Pallas) [A report on the nests of the harvest mouse (Micromys minutus Pallas)]. Lynx, n. s., 1: 19-20 (in Czech, with a summary in German).

Hodkové Z., 1979: Drobní savci z území ČSSR ve sběrech pracovníků Parazitologického ústavu ČSAV v letech 1953-1976 [Small mammals from the territory of Czechoslovakia collected by workers of the Institute of Parasitology of the Czechoslovakian Academy of Sciences in 1953-1976]. Lynx, n. s., 20: 45-74 (in Czech). 
HŮRKa L., 1981: Kleinsäuger in der Nahrnung der Schleiereule (Tyto alba guttata Brehm) in Westböhmen. Folia Musei Rerum Naturalium Bohemiae Occidentalis, Plzen̆, Zoologica, 15: 1-19.

Vohralík V. \& Lazarová J., 1998: Drobní savci (Insectivora, Rodentia) Horního Poohří v potravě sovy pálené (Tyto alba) [Small mammals (Insectivora, Rodentia) of the Horní Poohří region (Czech Republic) in the food of the barn owl (Tyto alba)]. Lynx, n. s., 29: 43-56 (in Czech, with an abstract in English). 